\title{
Ellenőrző lista hatása a légútbiztosítás korai szövődményeire felnőttekben
}

\author{
Szǘcs Zoltán Pál dr. ${ }^{1}$ - Farkas János dr. ${ }^{1}$ - Schimert Péter dr. ${ }^{1}$ \\ Baranyai Zsolt dr. ${ }^{2}$ - Dinya Elek dr. ${ }^{3}$
}

'Péterfy Kórház-Rendelőintézet és Manninger Jenő Országos Traumatológiai Intézet, Aneszteziológiai és Intenzív Betegellátó Osztály, Budapest

${ }^{2}$ Semmelweis Egyetem, Általános Orvostudományi Kar, I. Sebészeti Klinika, Budapest

${ }^{3}$ Semmelweis Egyetem, Egészségügyi Közszolgálati Kar, Digitális Egészségtudományi Intézet, Budapest

Bevezetés: Az általános anesztézia szerves része a légútbiztosítás, melynek helytelen végzése súlyos rövid és hosszú távú szövődményekhez vezethet.

Célkitüzés: Azt mértük fel, hogy a légútbiztosítás lépéseit ellenőrző lista alkalmazása csökkenti-e a szövődmények számát intézetünkben.

Módszer: Obszervációs, prospektív, kontrollált vizsgálatunk keretében ellenőrző listát és adatgyüjtő lapot készítettünk. Egy hónapig ellenőrző lista nélkül, egy hónapig az ellenőrző lista birtokában történt az összes légútbiztosítás. A légútbiztosítási manőverek kimenetelét és az ehhez köthető korai szövődmények előfordulását értékeltük az ellenőrző lista bevezetése előtt és után. Elsődleges végpont: a váratlan nehéz légút incidenciája. Másodlagos végpontok: a nehéz intubáció, a sikeres első intubáció, az aspiráció, a keringésleállás, a posztindukciós hipotenzió és deszaturáció, a lágy részek, fogak sérülései. Eredményeinket a szövődmények kockázatát ismerten befolyásoló tényezőkre (a beavatkozások sürgőssége, az orvosok tapasztalata) is korrigáltuk.

Eredmények: Az ellenőrző lista bevezetése előtti $(\mathrm{n}=439)$ és az azt követő ( $\mathrm{n}=423)$ időszak eseteit értékelve az akut szövődmények gyakoriságában nem találtunk különbséget. Az elsődleges végpontban $(7,29 \%$ és 6,14\%) nem volt érdemi differencia $(1,15 \%, 95 \% \mathrm{CI}:-2,26 \%-4,56 \%, \mathrm{p}=0,5)$. A másodlagos, illetve járulékos végpontok tekintetében sem találtunk különbséget. A kockázati tényezőkre való korrekció után sem volt hatása az ellenőrző listának a szövődmények gyakoriságára.

Következtetés: Intézetünkben az ellenőrző lista bevezetése önmagában nem eredményezett érdemi változást a légútbiztosítás rövid távú szövődményeinek kockázatában.

Orv Hetil. 2019; 160(26): 1025-1035.

Kulcsszavak: légútbiztosítás, betegbiztonság, minőségjavulás, ellenőrző lista, kimenetel

\section{The impact of a checklist on the short-term complications of airway management in adults}

Introduction: Airway management is an integral part of general anaesthesia, which may lead to severe short- and long-term complications.

Aim: We assessed whether the application of a checklist for the steps of airway management reduces the number of complications in our institute.

Method: In our observational, prospective, controlled study we made a checklist and a data collection sheet. Each airway management was performed for one month without the checklist and then for one month in the possession of the checklist. We evaluated the outcome of airway maneuvers and the occurrence of related early complications before and after the introduction of the checklist. The primary endpoint was the incidence of unexpected difficult airway. The secondary endpoints were difficult intubation, successful first intubation, aspiration, cardiac arrest, postinduction hypotension and desaturation, soft tissues/teeth injuries. Our results were also corrected for factors that affect the risk of complications (urgency of interventions, medical experience).

Results: We did not find any difference in the frequency of acute complications before the introduction of the checklist $(n=439)$ and during the subsequent period $(n=423)$. At the primary endpoint $(7.29 \%$ and $6.14 \%)$, there was no substantive difference $(1.15 \%, 95 \% \mathrm{CI}:-2.26 \%-4.56 \%, \mathrm{p}=0.5)$. No differences were found regarding the secondary and other endpoints. Following the correction of risk factors, there was no impact of the checklist on the incidence of complications. 
Conclusion: The introduction of the checklist in itself did not result in a significant change in the risk of short-term complications of airway management in our institution.

Keywords: airway management, patient safety, quality improvement, checklist, outcome

Szúcs Z, Farkas J, Schimert P, Baranyai Zs, Dinya E. [The impact of a checklist on the short-term complications of airway management in adults]. Orv Hetil. 2019; 160(26): 1025-1035.

(Beérkezett: 2019. február 4.; elfogadva: 2019. március 3.)

\section{Rövidítések}

$\mathrm{AM}=\operatorname{arcmaszk} ; \mathrm{AML}=$ arcmaszkos lélegeztetés; ASA = (American Society of Anesthesiologists) Amerikai Aneszteziológiai Társaság; $\mathrm{CI}=$ (confidence interval) konfidenciaintervallum; DAS $=($ Difficult Airway Society $)$ Nehéz Légút Társaság; ET = endotrachealis; ETI = endotrachealis intubáció; IKEB = Intézmény Kutatásetikai Bizottsága; LM = laringeális maszk; LML = laringeális lélegeztetés; MAITT = Magyar Aneszteziológiai és Intenzív Terápiás Társaság; NAP4 $=($ National Audit Project 4$)$ Nemzeti Ellenőrzési Projekt 4; NI = nehéz intubáció; RR = relatív rizikó; $\mathrm{SatO}_{2}=$ oxigénszaturáció

A műtétek és egyes diagnosztikai eljárások szerves része a légútbiztosítás. A beavatkozások túlnyomó része eseménytelenül zajlik, azonban egy nehéz légúti helyzet még napjainkban is komoly kihívás elé állíthatja a szakembereket.

A nehéz légút a definíció szerint az, ha egy hagyományosan képzett aneszteziológus nehézséget tapasztal lélegeztetés (AM/LM) és/vagy endotrachealis intubáció során [1]. A súlyos szövődmények incidenciája alacsony, de a beavatkozások nagy száma miatt jelentőségük mégsem elhanyagolható. A betegbiztonság növelésének igénye ezért számos kezdeményezést hívott életre, mint például az ASA, a DAS ajánlásai $[1,2]$, a magas áramlású, nazális oxigén [3], a 'vortex' szemlélet [4], nehéz légút esetén riasztható team [5], a légútbiztosítási auditok $[6,7]$, a lezárt peres ügyek adatbázisainak elemzései $[8,9]$ stb. A felsorolt módszerek ellenére egységes nemzetközi szemlélet és gyakorlat mégsem alakult ki. A gyakran szuboptimális körülmények miatt pedig továbbra is jelentős a napjaink lehetőségei és az elvárások között húzódó biztonsági rés [10]. A legújabb ajánlások már képesek átfogó iránymutatást adni a biztonságos légútbiztosításhoz, ugyanakkor a legfontosabb lépésekre emlékeztető ellenőrző listák használata még nem számít rutinszerű tevékenységnek. Intézetünkben az idegsebészeti, szájsebészeti, traumatológiai esetek légútbiztosítása gyakran jelent kihívást az aneszteziológusok számára. A speciális beteganyag miatt feltételeztük, hogy a nehéz légúti helyzetek aránya magasabb (6-10\%) lehet, mint az átlagpopulációban előfordulóké $(3,3-5,8 \%)$ [11, 12]. Feltételeztük továbbá, hogy egy légútbiztosítási ellenőrző lista [13] helyi viszonyokra adaptált változatának bevezetése csökkenti a váratlan nehéz légúti események és az ezzel kapcsolatos szövődmények számát.

\section{Módszer}

\section{Vizsgálati terv}

A SQUIRE 2.0 irányelv (http://squire-statement.org) ajánlásait figyelembe véve egy minőségjavítási kezdeményezés előtti és utáni időszak obszervációs, prospektív, kontrollált vizsgálatát végeztük, egy centrumban. Munkánk az Intézmény Kutatásetikai Bizottságának (IKEB) jóváhagyásával (nyilvántartási szám: 2/2018) történt. Vizsgálatunkhoz adatlapot és ellenőrző listát készítettünk. A mütőkben, az intenzív osztályon és a sokktalanítóban egy hónapig az ellenőrző lista nélkül, majd egy hónapig az ellenőrző lista birtokában végeztük az összes légútbiztosítást. A munkafolyamatokon, protokollokon nem változtattunk. A légútbiztosítási manőverek kimenetelét és az ehhez köthető szövődmények előfordulását az ellenőrző lista bevezetése előtti és utáni időszakra vonatkozóan értékeltük.

\section{A vizsgálat helye és résztvevői}

A vizsgálat 2018. április 1 -jétől 2018. május 31-ig a budapesti Péterfy Kórház-Rendelőintézet és Manninger Jenő Országos Traumatológiai Intézet Aneszteziológiai és Intenzív Betegellátó Osztályán történt. Az adatok szolgáltatásában minden, a cikk írásában nem érintett aneszteziológus rezidens, szakorvosjelölt és szakorvos részt vett. A vizsgálat időtartama alatt nem volt érdemi különbség az orvosok végzettsége, létszáma, beosztása és ledolgozott óraszáma között.

\section{A betegek bevonási és kizárási kritériumai}

Az ellenőrző lista bevezetése előtt vizsgált periódusban 570, az ellenőrző lista birtokában 619 légútbiztosítás történt. Értékelhető adatlap 491, illetve 484 esetről készült. Az intenzív osztályról mütétre, más intézményből a sürgősségi részlegre vagy az intenzív osztályra már intubálva került betegek eseteit nem gyújtöttük. A laringeális maszk bevezetését és az endotrachealis intubációt megelőző maszkos lélegeztetés minőségét külön nem vizsgáltuk. A 12 éven aluli betegek kizárását követően 439 , illetve 423 adatlapot dolgoztunk fel (1. ábra). A kizárásra nem jogi kategória, hanem célszerúbbnek és logi- 
kusabbnak számító irodalmi adatok alapján került sor. Bár egyértelmú határ (felnőtt/gyermek) nem húzható, anatómiai és fiziológiai paraméterek alapján a 12 éves kor kompromisszummentes határértéknek számít [14], ráadásul vannak adatok, érvek alacsonyabb életkorok mellett is (NAP4: 10 év, DAS-ajánlások: 8 év).

\section{A vizsgálat menete}

$\mathrm{Az}$ adatgyưjtő lap (2. ábra) bevezetését oktatás előzte meg (3. ábra). 1 hónapig minden egyes légútbiztosítás során kitöltettük az adatgyưjtő lapot. A második adatgyưjtési periódus előtt került ismertetésre és bevezetésre

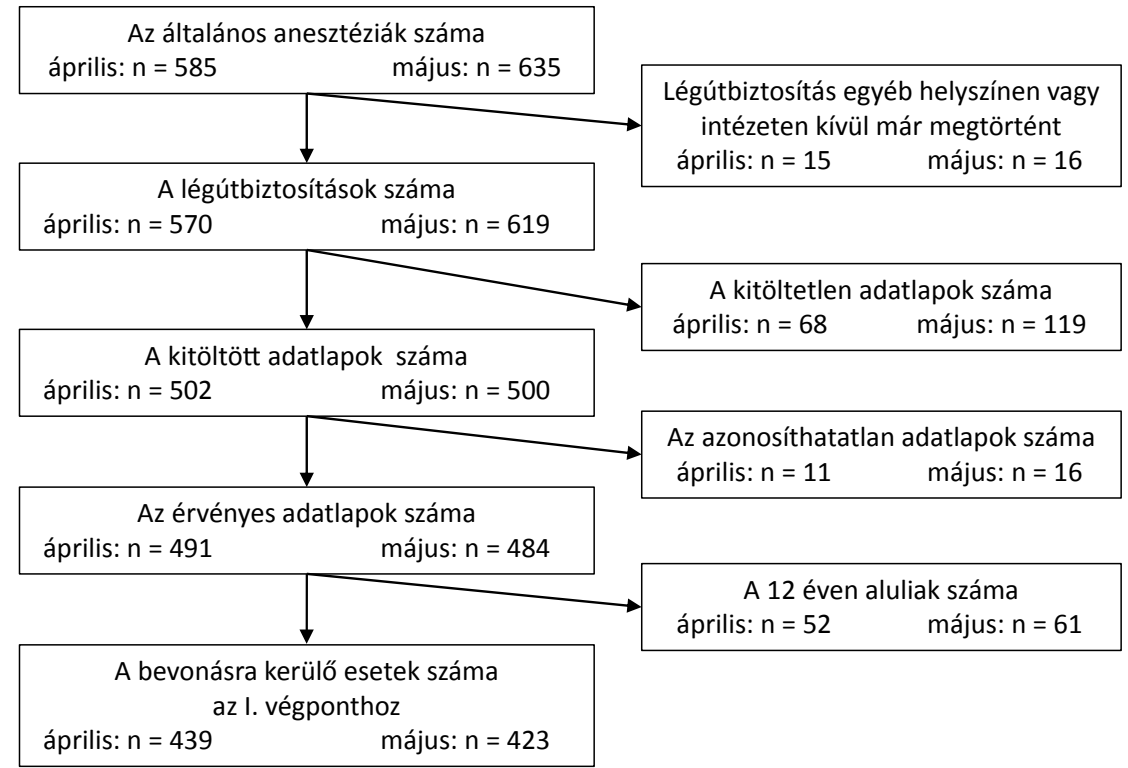

1. ábra

$\mid \begin{aligned} & \text { A betegek bevonási és kizárási kritériumai } \\ & \mathrm{n}=\text { feldolgozott, értékelt adatlapok száma }\end{aligned}$

\section{Légútbiztosítás: adatok (MŰTŐ / SOKKTALANÍTÓ / ITO) dátum: h/n:}

1. Orvos:

2. Beteg:

3. Helyszín:

4. Beavatkozás:

$\begin{aligned} & \text { Rezidens } \\ & \text { Kora (év)___ } \\ & \text { Mútő }\end{aligned}$ /
Tervezett

Szakorvosjelölt / Neme: Férfi /

ITO

Sürgős

5. Kezdő paraméterek a légútbiztosítás előtt:

$\mathbf{R R}$

hgmm
Szakorvos

Nő

Sokktalanító

$\mathrm{SatO}_{2}$ $\%$

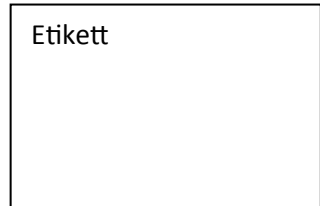

Légútbiztosítás:

6. Nehéz intubáció várható?

7. Módszer:

8. Indukció:

I / N

9. Relaxáns intubációhoz:

10. Eszköz/technika:

11. Az intubáció kimenetele

12. Intubációs kísérletek száma:

LMA Maszkos n ( \pm OFT)

Laringoszkóp VideoL Fiberoszkóp

Sikertelen

3

A légútbiztosítással kapcsolatos szövödmények:

1. Aspiráció

2. Deszaturáció $\left(\mathrm{SpO}_{2}<90 \%\right) \quad$ (indukció után $\leq 5$ percig)

3. Hipotenzió (BP, Ps<90 Hgmm) (indukció után $\leq 5$ percig)

4. Keringés leállása

5. Fog jelentősebb sérülése/elvesztése

6 . Lágy rész sérülése/vérzése

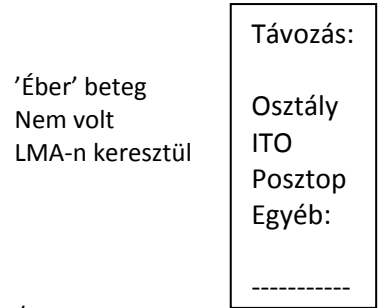

na
na
na
na
na
na

Megjegyzés:

Hátoldalon!

\section{Utánkövetés, másnap}

7. Rekedtség

8. Stridor

9. Nyelési nehézség/'torok'fájdalom/

$\begin{array}{lllll}\text { I } & / & \mathrm{N} & / & \text { na } \\ \mathrm{I} & / & \mathrm{N} & / & \text { na } \\ \mathrm{I} & \text { / } & \mathrm{N} & / & \text { na }\end{array}$

\footnotetext{
Adatgyújtő lap
}

$\mathrm{BP}$ = blood pressure; ETI = endotrachealis intubáció; $\mathrm{I}$ = igen; ITO = Intenzív Terápiás Osztály; LMA = laringeális maszk; $\mathrm{N}=$ nem; $\mathrm{n}=$ feldolgozott, értékelt adatlapok száma; OFT $=$ oropharyngealis tubus; $\mathrm{Ps}=$ pressure, systolic; $\mathrm{SCC}=$ szukcinilkolin; $\mathrm{SpO}_{2}=$ oxigénszaturációs index 
A helyi gyakorlatra adaptált/módosított légútbiztosítási ellenörző lista

Légútbiztosítási ellenőrző lista (műtő/intenzív osztály/sokktalanító)

A) Felmérés-felismerés (Az alábbiak ellenőrzése megtörtént?)

1. A légút felmérése (Várható-e nehéz légút?)

$\mathrm{I} / \mathrm{N} / \mathrm{na}$

2. Aspiráció veszélye?

$\mathrm{I} / \mathrm{N} / \mathrm{na}$

3. Nyaki csigolyák sérülése?

$\mathrm{I} / \mathrm{N} / \mathrm{na}$

4. Gyógyszer ellenjavallata? (Például Se K-scc.) $\mathrm{I} / \mathrm{N} / \mathrm{na}$

B) Stratégia: tervek/csapatmunka

(Az alábbiak közlése, tisztázása megtörtént?)

5. A terv sikertelensége esetén B terv ismertetése?

$\mathrm{I} / \mathrm{N} / \mathrm{na}$

6. Sikertelen légútbiztosítás esetén: az ébresztés opció? I/N/na

7. A potenciális segítő személye ismert, elérhető? I/N/na

8. A szerepek kiosztása nehézség esetén?

$\mathrm{I} / \mathrm{N} / \mathrm{na}$

C) Eszközök (Elérhetöségük + ellenörzésük megtörtént?)

9. $\mathrm{ETCO}_{2}$-mérő

$\mathrm{I} / \mathrm{N} / \mathrm{na}$

10. LMA

$\mathrm{I} / \mathrm{N} / \mathrm{na}$

11. Nehézlégút-eszközök (VL, fiberoszkóp, ILMA,

$\mathrm{I} / \mathrm{N} / \mathrm{na}$ sebészi légút

D) Optimalizálás (Az alábbiak megtörténtek?)

12. Speciális fektetés nehéz intubáció esetén

(Fej-nyak helyzet [hallójárat-jugulum viszonya/túlsúlyos beteg: ramping])

13. Preoxigenáció (nazális $\mathrm{O}_{2} / \mathrm{CPAP} / \mathrm{NIV} / \mathrm{ETO}_{2}>85 \% \quad \mathrm{I} / \mathrm{N} / \mathrm{na}$ vagy $>3$ perc)

14. A hemodinamika rendezése intubáció előtt:

- Folyadék (bólus/vazopresszor)

- Megfontolt narkózisindukció

(dózisredukció/ \pm ketamin)

\section{E) Dokumentáció (Megtörtént?)}

15. Nehéz légúti helyzet leírása jegyzőkönyvben/ epikrízisben

$\mathrm{I} / \mathrm{N} / \mathrm{na}$

$\mathrm{CPAP}=$ folyamatos pozitív légúti nyomás; $\mathrm{ETCO}_{2}=$ kilégzésvégi szén dioxid-koncentráció; $\mathrm{ETO}_{2}=$ kilégzésvégi oxigénkoncentráció; I = igen; ILMA = intubációs laringeális maszk; LMA = laringeális maszk; $\mathrm{N}=$ nem; na = nincs adat; NIV = nem invazív lélegeztetés; $\mathrm{scc}=$ szukcinilkolin; $\mathrm{VL}=$ videolaringoszkóp

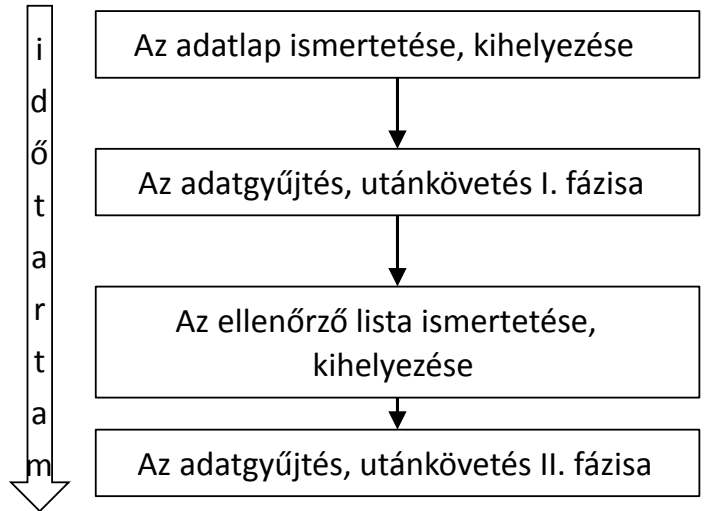

3. ábra | A vizsgálat felépítése és időtartama
2. táblázat $\mid$ Az arcmaszkos lélegeztetés klasszifikációja és definíciója Han és mtsai szerint

\begin{tabular}{ll}
\hline Klasszifikáció & Definíció/leírás \\
\hline 0. kategória & Arcmaszkos lélegeztetés nem történt \\
1. kategória & Eseménytelen arcmaszkos lélegeztetés \\
2. kategória & OFT vagy egyéb segédeszköz kellett \\
3. kategória & $\begin{array}{l}\text { Nehéz arcmaszkos lélegeztetés (inadekvát, 2 személy } \\
\text { kellett) }\end{array}$ \\
4. kategória & Sikertelen arcmaszkos lélegeztetés \\
\hline
\end{tabular}

OFT $=$ oropharyngealis tubus

az ellenőrző lista (1. táblázat). A listát minden mútői állomásnál, intenzív osztályos kórteremben, orvosi szobában és a sokktalanítóban is elhelyeztük. A második, 1 hónapos adatgyưjtési periódus az ellenőrző lista ismeretében történt. Az adatlappal rendelkező betegeket másnap ( $\leq 24$ óra) felkerestük utánkövetés céljából.

Az alábbi definíciókat alkalmaztuk a légútbiztosítási manőverek egységes kivitelezése és megítélése érdekében.

Inadekvát arcmaszkos vagy laringeális maszkos lélegeztetés: a maszk rosszul illeszkedik, az elszivárgó levegő mennyisége nem tolerálható, a gáz áramlása jelentősen akadályozott [1]. Az egyik legelfogadottabb klasszifikációt Han és mtsai [15] dolgozták ki, munkánk során mi is ezt használtuk (2. táblázat). Nehéz laringeális maszk behelyezés: kettő vagy több kísérlet történik, attól függetlenül, hogy a légúti anatómia kóros vagy normális. Sikertelen laringeális maszkos lélegeztetés: az eszközt el kell távolítani, és intubációra van szükség [1]. Nehéz laringoszkópia: többszöri kísérlet ellenére sem sikerül látótérbe hozni a hangrést. Nehéz ETI: 2 vagy több kísérlet történik, segédeszköz és/vagy speciális, indirekt technika szükséges. Sikertelen intubáció: több kísérlet ellenére sem helyezhető be a tubus [1].

A légútbiztosítás előtt az orvos tapasztalatára, a betegek korára és nemére, illetve a helyszínre és a sürgősségre vonatkozó adatokat, továbbá az utolsó, pulzoximéterrel mért szaturációs értéket és a vérnyomás szisztolés értékét rögzítettük. A nehéz légút (nehéz lélegeztetés és/vagy nehéz intubáció) valószínúségének felmérése ágy melletti tesztek, illetve anamnézis felvétele alapján történt. A már korábban premedikált betegek esetén a beavatkozást végző megítélése volt a döntő az adatlap kitöltésekor. A felmérést nehezítette, hogy a légútbiztosítási manőverek nehézségének objektív, precíz és standardizált definíciója nincs. A kimenetel továbbá függ az operátor képzettségétől, az alkalmazott technikától és a beteg légútjától. A preoxigenizációt elektív esetben 3 percben, sürgős esetben 1 percben ( 8 mély légvétel) határoztuk meg. Az alacsony vérnyomásérték rendezése folyadék és/vagy vazopresszor adását jelentette.

A légútbiztosítás kivitelezése kapcsán a választott módszer, az indukció és az izomrelaxáció gyógyszerei, az 
alkalmazott eszköz, valamint a kísérletek száma és kimenetele került az adatlapra.

A légútbiztosításhoz köthető, általunk vizsgált korai szövődmények az alábbiak voltak: pulmonalis aspiráció, posztindukciós hipotenzió és/vagy deszaturáció, keringésleállás, lágyrész-sérülések, rekedtség, stridor, nyelési nehézség/torokfájdalom. Posztindukciós deszaturációnak véleményeztük, ha a légútbiztosítással összefüggésbe hozhatóan csökkent $90 \%$ alá a pulzoximéterrel monitorozott $\mathrm{SatO}_{2}$, melynek kiindulási értéke $\geq 90 \%$ volt $[16$, 17]. A súlyos $(<80 \%)$, valamint kritikus $(<70 \%)$ szaturációs értékek [18] vizsgálata nem volt cél. Posztindukciós hipotenziónak a szisztolés vérnyomásérték 90 Hgmm alá csökkenését tekintettük. A hipotenzió nélküli keringési instabilitást, ahol a vérnyomásesés mértéke a kiindulási értékhez képest $\geq 20 \%$ volt, nem vizsgáltuk. A vizsgált paraméterekben a narkózis indukcióját követő 5 percen belüli értékeket tekintettük mérvadónak. A lágy részek sérülését jelentette az ajak, a nyelv, a garat nyálkahártyájának vérzése, valamint véres váladék észlelése a laringeális maszkon, laringoszkópon. A fog(ak) sérülését törés, kimozdulás/elvesztés okozhatta.

\section{Végpontok}

Elsődleges végpontként a váratlan nehéz légút (nehéz lélegeztetés és/vagy nehéz intubáció) előfordulását jelöltük meg (4. ábra).

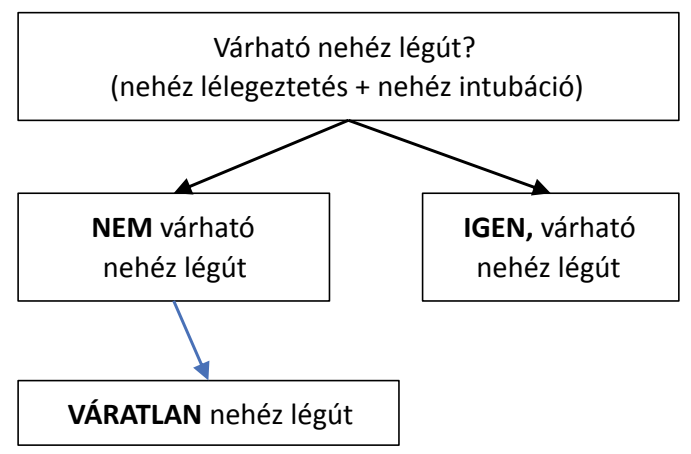

4. ábra | A vizsgálat elsődleges végpontjának meghatározása
3. táblázat |A kizárt esetek száma az utánkövetés kapcsán nyert adatok elemzéséhez

\begin{tabular}{lcc}
\hline Kizáró okok & Április & Május \\
\hline $\begin{array}{l}\text { Elégtelen kommunikáció (dementia, koponya- } \\
\text { sérülés, afázia) }\end{array}$ & 8 & 8 \\
$\begin{array}{l}\text { Nyakon végzett (idegsebészeti, érsebészeti, } \\
\text { pajzsmirigy-) mütét }\end{array}$ & 5 & 2 \\
Arckoponyasérülés, szájsebészeti mútét & 3 & 1 \\
$\begin{array}{l}\text { Tartós intubáció/kritérium: több, mint 24 óra } \\
\text { (CPR, egyéb ok) }\end{array}$ & 6 & 4 \\
$\begin{array}{l}\text { Már meglévő akut vagy krónikus panaszok } \\
\text { (légúti infekció, neoplasia) }\end{array}$ & 0 & 2 \\
$\begin{array}{l}\text { Nincs adat: eltávozott (1 napos sebészet, más } \\
\text { intézetbe áthelyezés stb.) }\end{array}$ & 88 & 108 \\
Elhunyt & 0 & 2 \\
\hline Összesen & 110 & 127 \\
\hline
\end{tabular}

CPR = szív-tüdő újraélesztés

A másodlagos végpontokhoz a légútbiztosítási manóverek több kimeneteli adata, az adatlapon felsorolt azonnali, valamint további kezelést is igénylő szövődmények kerültek: súlyos tápcsatornai/légúti sérülés, nem tervezett tartós intubáció/lélegeztetés/sebészi légút, hypoxiás agysérülés, halál. A deszaturációval és hipotenzióval járó esetek elemzéséhez kizártuk a kiindulási adatokkal nem rendelkező, illetve optimalizálás ellenére is hypoxiás (április: $\mathrm{n}=40 /$ május: $\mathrm{n}=37$ ), hipotenziós (április: $\mathrm{n}=19 /$ május: $\mathrm{n}=22$ ) betegeket (5. ábra).

Az utánkövetés során nyert adatok szolgáltatták a járulékos végpontokat: rekedtség, stridor, nyelési nehézség/ torokfájdalom. Az eredeti adatbázisból szintén kizárásra kerültek esetek (3. táblázat, 5. ábra).

A végpontokat a könnyebb áttekintés érdekében táblázatba foglaltuk (4. táblázat).

\section{Mintaméret}

Elsődleges végpontként a váratlan nehéz légút előfordulását jelöltük meg. Feltételeztük, hogy 50\%-os csökkenés

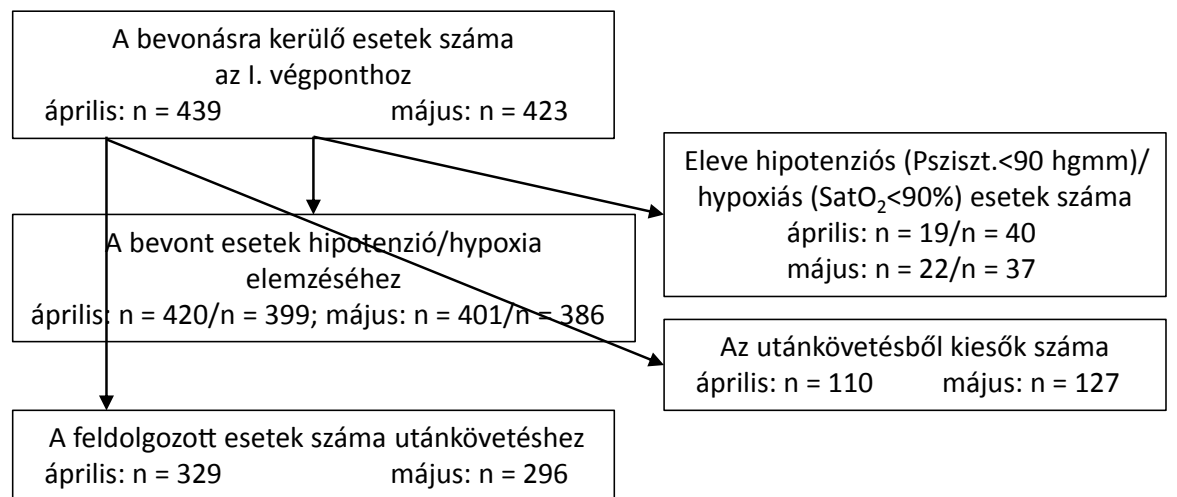

5. ábra

Kizárási kritériumok adatelemzés kapcsán

$\mathrm{n}$ = feldolgozott, értékelt adatlapok száma; Psziszt. = szisztolés nyomás; SatO $\mathrm{O}_{2}=$ oxigénszaturáció 
4. táblázat |A végpontok felsorolása

\section{Elsödleges végpont}

Váratlan nehéz légúti esetek száma

II/A Másodlagos végpontok

Várható nehéz légút, és igazolódott

Összes nehéz légúti esetek száma

Váratlan nehéz légút/összes nehéz légút aránya

Aspiráció, keringésleállás

További kezelést igénylő egyéb súlyos szövődmény

Definitív/biológiai halál

AM-narkózis: nehéz, sikertelen

LM-narkózis: nehéz, sikertelen (ETI-ra váltás)

ETI: nehéz, sikertelen

ETI: váratlanul nehéz

Váratlanul nehéz ETI/összes nehéz ETI aránya

ETI: elsőre sikeres

ETI: sikeres $(2 / 3 /$ több, mint 3 kísérlet $)$

Fog(ak) elvesztése/sérülése/lágy rész sérülése, vérzése

II/B Másodlagos végpontok (esetek kizárása után)

Posztindukciós deszaturáció, hipotenzió

III. Járulékos végpontok (utánkövetéssel, esetek kizárása után)

Rekedtség, stridor, torokfájdalom/nyelési nehézség

$\mathrm{AM}=$ arcmaszk; ETI = endotrachealis intubáció; LM = laringeális maszk

(incidencia: $10 \% \rightarrow 5 \%$ ) érhető el az ellenőrző lista bevezetését követően. $\alpha=0,05$ és Power $=80 \%$ értéket használva, legalább $434 / 434$ beteg bevonását kalkuláltuk csoportonként.

\section{Statisztikai analizis}

$\mathrm{Az}$ adatok rögzítésére táblázatkezelő programot (Excel MSO, 2016; Microsoft, Redmond, WA, Amerikai Egyesült Államok [USA]) használtunk. A folyamatos és normáleloszlást követő változók leírására paramétereket (átlag \pm SD), összehasonlításukhoz független kétmintás t-tesztet, a nemek közti összehasonlításhoz Pearson-féle khi-négyzet-tesztet alkalmaztunk. Kategorikus változók esetén abszolút és relatív gyakoriságokat adtunk meg. Az ellenőrző lista előtti és utáni időszak arányainak összevetéséhez z-tesztet használtunk. Alcsoportok vizsgálata esetén a kockázat mérésére relatív kockázatot (RR) kalkuláltunk, khi-négyzet-teszttel és Fischer-féle egzakt teszttel kiegészítve, illetve 95\%-os konfidenciaintervallumot (CI) számoltunk.

Statisztikailag szignifikánsnak a p $<0,05$ értéket tekintettük. A statisztikai elemzésre az SPSS (25.0, IBM, Armonk, NY, USA) programot alkalmaztuk.

\section{Eredmények}

Az első hónapban 502 adatlap gyưlt össze, vagyis a kitöltési arány $(502 / 570)$ 88\%-nak bizonyult. 491 adatlap volt értékelhető. A 12 éven aluliak (52) kizárása után 439 adatlap került bevonásra az elsődleges végpont elemzéséhez. A második hónapban 500 adatlapot adtak le, így a kitöltési hajlandóság (500/619) 80\%-ot ért el. 484 eset volt értékelhető, melyekből a 12 év alattiak (61) kizárását követően 423 eset került elemzésre. A két hónap között nem volt különbség a betegek életkorát $(\mathrm{p}=0,4829)$ és a nemek arányait $(\mathrm{p}=0,5571)$ tekintve. A légútbiztosítások túlnyomó többsége a mütőkben történt. Az esetek valamivel több mint 60\%-a tervezett beavatkozás volt. A beavatkozások összegzésekor adódó

5. táblázat |Adatlapok, beavatkozások és a betegek adatai

\begin{tabular}{|c|c|c|c|}
\hline Jellemző adatok & $\begin{array}{c}\text { Április, } \\
\text { ellenőrző lista } \\
\text { előtti periódus } \\
\text { n = } 439(\%)\end{array}$ & $\begin{array}{c}\text { Május, } \\
\text { ellenőrző lista } \\
\text { melletti } \\
\text { periódus } \\
\mathrm{n}=423(\%)\end{array}$ & $\begin{array}{l}\text { Különb- } \\
\text { ség } \\
\text { p }\end{array}$ \\
\hline $\begin{array}{l}\text { Kezdeményezett légútbiz- } \\
\text { tosítás, n }\end{array}$ & 570 & 619 & \\
\hline Kitöltött adatlap, n (\%) & $502(88)$ & $500(80)$ & \\
\hline Bevonásra kerülö adatlap, $n$ & 439 & 423 & \\
\hline Rezidens végezte, n (\%) & $42(9,57)$ & $82(19,38)$ & \\
\hline $\begin{array}{l}\text { Szakorvosjelölt végezte, } \\
\mathrm{n}(\%)\end{array}$ & $161(36,67)$ & $144(34,04)$ & \\
\hline Szakorvos végezte, n (\%) & $236(53,76)$ & $197(46,58)$ & \\
\hline Légútbizt. műtőben, n (\%) & $429(97,72)$ & $417(98,58)$ & \\
\hline $\begin{array}{l}\text { Légútbizt. intenzív } \\
\text { osztályon, } \mathrm{n}\end{array}$ & 1 & 4 & \\
\hline Légútbizt. sokktalanítóban, n & 9 & 2 & \\
\hline $\begin{array}{l}\text { Tervezett beavatkozás, } \\
\mathrm{n}(\%)\end{array}$ & $269(61,27)$ & $267(63,12)$ & \\
\hline $\begin{array}{l}\text { Halasztott és sürgős } \\
\text { beavatkozás, n }\end{array}$ & 170 & 156 & \\
\hline Tervezetten AM-narkózis, n & 5 & 12 & \\
\hline Tervezetten LM-narkózis, n & 196 & 188 & \\
\hline $\begin{array}{l}\text { Tervezetten LM (sikerte- } \\
\text { len)- ETI, n }\end{array}$ & 7 & 3 & \\
\hline Összes LM-narkózis, n & 203 & 191 & \\
\hline Tervezetten ETI, n & 231 & 221 & \\
\hline Összes ETI, n & 238 & 224 & \\
\hline $\begin{array}{l}\text { Betegek kora: } \\
\text { minimum-maximum } \\
\text { átlag } \pm \text { SD }\end{array}$ & $\begin{array}{c}12-104 \\
52,31 \pm 21,6\end{array}$ & $\begin{array}{c}12-97 \\
53,35 \pm 21,9\end{array}$ & 0,4829 \\
\hline $\begin{array}{r}\text { Betegek neme: férfi } \\
\text { nó }\end{array}$ & $\begin{array}{l}229(52 \%) \\
210(48 \%)\end{array}$ & $\begin{array}{l}210(50 \%) \\
213(50 \%)\end{array}$ & $\begin{array}{l}0,5571 \\
0,5571\end{array}$ \\
\hline
\end{tabular}

$\mathrm{AM}=\operatorname{arcmaszk} ; \mathrm{ETI}=$ endotrachealis intubáció; $\mathrm{LM}=$ laringeális maszk; $\mathrm{n}=$ feldolgozott, értékelt adatlapok száma; $\mathrm{SD}=$ standard deviáció 
6/A táblázat | Alapadatok és az elsődleges végpont

\begin{tabular}{|c|c|c|c|}
\hline $\begin{array}{l}\text { Légútbiztosítási manőverek; } \\
\text { szövődmények }\end{array}$ & $\begin{array}{l}\text { A szövődmények gyakorisága } \\
\text { az összes értékelhető adatlap arányában; } \\
\text { ellenőrző lista előtt } \\
\text { április: } n=439(\%)\end{array}$ & $\begin{array}{l}\text { A szövődmények gyakorisága } \\
\text { az összes értékelhető adatlap arányában; } \\
\text { ellenőrző lista birtokában } \\
\text { május: } n=423(\%)\end{array}$ & $\begin{array}{l}\text { Statisztika: } \\
\text { RD \% (95\% CI), p }\end{array}$ \\
\hline Nem várható nehéz légút & $388(88,38 \%)$ & $384(90,78 \%)$ & $2,4(-1,7-6,5), 0,2496$ \\
\hline Várható nehéz légút & $51(11,62 \%)$ & $39(9,22 \%)$ & - \\
\hline \multicolumn{4}{|l|}{ I. Elsödleges végpont } \\
\hline Váratlan nehéz légút & $32(7,29 \%)(14$ LM, 18 ETI $)$ & $26(6,14 \%)(10 \mathrm{LM}+16 \mathrm{ETI})$ & $1,15(-2,26-4,56), 0,5006$ \\
\hline
\end{tabular}

$\mathrm{CI}=$ konfidenciaintervallum; ETI = endotrachealis intubáció; LM = laringeális maszk; n = feldolgozott, értékelt adatlapok száma; RD = rizikódifferencia

nagyobb esetszámot az egyes légútbiztosítási manőverek kombinációja eredményezte (5. táblázat).

$\mathrm{Az}$ elsődleges végpont ( $6 / A$ táblázat), vagyis a váratlan nehéz légút előfordulásában nem volt különbség $(7,29 \%$ és $6,14 \%, p=0,5006)$ a két hónap között.

A másodlagos végpontok részeként elemzett $(6 / B$ táblázat) beavatkozások, szövődmények ugyancsak nem igazoltak érdemi különbséget. Az esetek közel 10\%-ában vártak (11,62\% és 9,22\%) nehéz légutat az orvosok, de csak ezek negyede bizonyult valóban nehéznek. Tanulsá- gos, hogy az összes nehéz légúti ( $10,25 \%$ és $8,03 \%$ ) eset kb. 3/4-e (71\% és 76\%, $\mathrm{p}=0,5957)$ váratlanul lépett fel. A súlyos szövődmény ritka esemény volt. Aspiráció 2 alkalommal $(0,45 \%)$ csak az ellenőrző lista előtti periódusban történt, mely l esetben igényelt tartós lélegeztetést. Keringésleállás, mely definitív halálhoz vezetett, egyszer fordult elő az ellenőrző listás hónapban. Tervezetten csak arcmaszkos narkózis történt elenyésző számban, eseménytelenül. Laringeális maszk használata során problémát 7,88\%-ban és 5,23\%-ban $(\mathrm{p}=0,2901)$ talál-

6/B táblázat | A másodlagos végpontok elemzése kizárás előtt és után

\begin{tabular}{|c|c|c|c|}
\hline $\begin{array}{l}\text { Légútbiztosítási manőverek; } \\
\text { szövődmények }\end{array}$ & $\begin{array}{l}\text { A szövődmények gyakorisága az összes } \\
\text { értékelhető adatlap arányában; } \\
\text { ellenőrző lista előtt } \\
\text { április: } n=439 \text { (\%) }\end{array}$ & $\begin{array}{l}\text { A szövődmények gyakorisága az összes } \\
\text { értékelhető adatlap arányában; } \\
\text { ellenőrző lista birtokában } \\
\text { május: } n=423(\%)\end{array}$ & $\begin{array}{c}\text { Statisztika: } \\
\text { RD \% }(95 \% \mathrm{CI}), \mathrm{p}\end{array}$ \\
\hline \multicolumn{4}{|l|}{ II. Másodlagos végpontok } \\
\hline Összes NL & $45(32+13)(10,25 \%)$ & $34(26+8)(8,03 \%)$ & $2,22(-1,67-6,1), 0,2589$ \\
\hline Váratlan NL/Összes NL & $32 / 45=(71,11 \%)$ & $26 / 34=(76,47 \%)$ & $5,36(-14,5-23,6), 0,5957$ \\
\hline Aspiráció & $2(0,45 \%)$ & $0(0 \%)$ & na \\
\hline Keringésleállás & $0(0 \%)$ & $1(0,23 \%)$ & na \\
\hline $\begin{array}{l}\text { További kezelést igénylö } \\
\text { szövődmény }\end{array}$ & $\begin{array}{c}\mathrm{l}(0,22 \%) \\
\text { (aspiráció után lélegeztetés) }\end{array}$ & $0(0 \%)$ & na \\
\hline (Definitív halál) & $0(0 \%)$ & $1(0,23 \%)$ & na \\
\hline LM-narkózis: nehéz & $9 / 203(4,43 \%)$ & $7 / 191(3,66 \%)$ & $0,77(-3,4-4,9), 0,6990$ \\
\hline LM sikertelen (ETI kellett) & $7 / 203(3,45 \%)$ & $3 / 191(1,57 \%)$ & $1,88(-1,55-5,53), 0,2364$ \\
\hline Összes nehéz ETI & $29 / 238(12,18 \%)$ & $25 / 224(11,16 \%)$ & $1,02(-4,9-6,9), 0,7333$ \\
\hline ETI: sikertelen & $0 / 238$ & $0 / 224$ & na \\
\hline ETI: váratlanul nehéz & $18 / 238(7,56 \%)$ & $16 / 224(7,14 \%)$ & $0,42(-4,5-5,3), 0,8629$ \\
\hline ETI: elsőre sikeres & $213 / 238(89,5 \%)$ & $199 / 224(88,84 \%)$ & $0,66(-5,0-6,5), 0,8197$ \\
\hline ETI: több kísérletre sikeres & $25 / 238(10,5 \%)$ & $25 / 224(11,16 \%)$ & NS \\
\hline Fogak sérülése/elvesztése & $0(0 \%)$ & $1(0,23 \%)$ & na \\
\hline Lágy részek sérülése & $20(4,55 \%)$ & $9(2,13 \%)$ & $2,42 \%(-0,03-5), 0,0489$ \\
\hline \multicolumn{4}{|c|}{ II. Másodlagos végpontok, esetek kizárása után* } \\
\hline Kizárás utáni esetek száma & $399 *(439-40)$ & $386^{*}(423-37)$ & \\
\hline Posztindukciós deszaturáció & $9(2,25 \%)$ & $8(2,07 \%)$ & $0,18(-2,0-2,4), 0,8624$ \\
\hline Kizárás utáni esetek száma & $420 *(439-19)$ & $401 *(423-22)$ & \\
\hline Posztindukciós hipotenzió & $35(8,33 \%)$ & $38(9,48 \%)$ & $1,15(-2,7-5,1), 0,5630$ \\
\hline
\end{tabular}

$\mathrm{CI}=$ konfidenciaintervallum; ETI = endotrachealis intubáció; $\mathrm{LM}=$ laringeális maszk; $\mathrm{n}$ = feldolgozott, értékelt adatlapok száma; na = nincs adat; $\mathrm{NL}=$ nehéz légút; $\mathrm{NS}=$ nem szignifikáns; $\mathrm{RD}$ = rizikódifferencia 
6/C táblázat | Egyéb végpontok, másnapi utánkövetés alapján

\begin{tabular}{|c|c|c|c|}
\hline $\begin{array}{l}\text { Légútbiztosítási manőverek; } \\
\text { szövődmények }\end{array}$ & $\begin{array}{c}\text { A szövődmények gyakorisága az } \\
\text { összes értékelhető adatlap arányában; } \\
\text { ellenőrző lista előtt } \\
\text { április: } n=439 \text { (\%) }\end{array}$ & $\begin{array}{l}\text { A szövődmények gyakorisága } \\
\text { az összes értékelhető adatlap arányában; } \\
\text { ellenőrző lista birtokában } \\
\text { májjus: } n=423(\%)\end{array}$ & $\begin{array}{c}\text { Statisztika: } \\
\text { RD \% }(95 \% \text { CI }), p\end{array}$ \\
\hline \multicolumn{4}{|c|}{ III. Egyéb végpontok: utánkövetés: a köpetkezö napon, <24óra, kizárásokat követöen ** } \\
\hline KIZÁRÁS utáni esetek** & $329 * *(439-110)$ & $296^{* *}(423-127)$ & - \\
\hline Rekedtség összes & $62 / 329(18,85 \%)$ & $53 / 296(17,90 \%)$ & $0,95(-5,2-7), 0,7598$ \\
\hline Csak ETT & $29 / 168(17,26 \%)$ & $24 / 152(15,78 \%)$ & NS \\
\hline Csak LM & $33 / 152(21,71 \%)$ & $29 / 137(21,17 \%)$ & NS \\
\hline Csak AM & $0 / 4$ & $0 / 6$ & na \\
\hline \multicolumn{4}{|l|}{ ETT/nem ETT: } \\
\hline $\mathrm{RR}(95 \% \mathrm{CI}), \mathrm{p}$ & $0,81(0,52-1,28), 0,3745$ & $0,78(0,47-1,27), 0,3171$ & \\
\hline Stridor összes & $4 / 329(1,21 \%)$ & $5 / 296(1,68 \%)$ & $0,47(-1,6-2,8), 0,6218$ \\
\hline Csak ETT & $3 / 168(1,78 \%)$ & $4 / 152(2,63 \%)$ & NS \\
\hline Csak LM & $1 / 152(0,66 \%)$ & $1 / 137(0,73 \%)$ & NS \\
\hline Csak AM & $0 / 4$ & $0 / 6$ & na \\
\hline \multicolumn{4}{|l|}{ ETT/nem ETT: } \\
\hline $\mathrm{RR}(95 \% \mathrm{CI}), \mathrm{p}$ & $2,82(0,29-26,81), 0,3671$ & $3,76(0,42-33,27), 0,2333$ & \\
\hline Torokfájdalom/nyelési nehézség & $67 / 329(20,36 \%)$ & $44 / 296(14,86 \%)$ & $5,50(-0,5-11,4), 0,0726$ \\
\hline Csak ETT & $36 / 168(21,43 \%)$ & $22 / 152(14,47 \%)$ & NS \\
\hline Csak LM & $31 / 152(20,40 \%)$ & $22 / 137(16,06 \%)$ & NS \\
\hline Csak AM & $0 / 4$ & $0 / 6$ & na \\
\hline \multicolumn{4}{|l|}{ ETT/nem ETT: } \\
\hline $\mathrm{RR}(95 \% \mathrm{CI}), \mathrm{p}$ & $1,08(0,70-1,65), 0,7298$ & $0,94(0,54-1,62), 0,8263$ & \\
\hline
\end{tabular}

$\mathrm{AM}=\operatorname{arcmaszk} ; \mathrm{CI}=$ konfidenciaintervallum; $\mathrm{ETI}=$ endotrachealis intubáció; $\mathrm{ETT}=$ endotrachealis tubus; $\mathrm{LM}=$ laringeális maszk; $\mathrm{n}=$ feldolgozott, értékelt adatlapok száma; na = nincs adat; $\mathrm{NL}=$ nehéz légút; $\mathrm{NS}=$ nem szignifikáns; $\mathrm{RD}=$ rizikódifferencia; $\mathrm{RR}=$ relatív rizikó

tunk. Itt kb. az esetek felében sikertelen volt az eszköz használata, és intubációra tértek át. Sikertelen intubáció nem történt, de nehéznek 12,18\%-ban és 11,16\%-ban (p $=0,7333)$ bizonyult. A váratlan nehéz intubációk aránya szintén magas volt mindkét csoportban, $62 \%$ és $64 \%$ $(\mathrm{p}=0,8805)$. A sikeres első intubációk aránya csaknem $90 \%$-os volt $(89,5 \%$ és $88,84 \%, \mathrm{p}=0,8197)$. A határértékben szignifikáns csökkenést a minor szövődmények elemzésekor, lágy részek sérülése $(4,55 \%$ és $2,13 \%)$ kapcsán találtunk $(2,42 \%, 95 \% \mathrm{CI}:-0,03 \%-5 \%, \mathrm{p}=0,0489)$ : ilyen p-értéknél mégis óvatosan kell levonni a következtetést. Fogsérülés 1 alkalommal, a második hónapban fordult elő. A sikertelen optimalizálás miatti kizárásokat követôen (6/B táblázat) lehetett elemezni a légútbiztosítással összefüggésbe hozható hipotenziós $(8,33 \%$ és $9,48 \%$ ) és hypoxiás ( $2,25 \%$ és $2,07 \%$ ) eseteket, de szignifikáns eltérést itt sem találtunk.

A járulékos végpontokhoz (6/C táblázat) sorolt szövődmények (rekedtség, stridor, torokfájdalom/nyelési nehézség) összevetésére a már felsorolt kizáró tényezők miatt csökkent esetszám birtokában került sor. Lényeges különbség itt sem adódott, és az egyes alcsoportok (ET tubus - nem ET tubus) elemzése sem hozott meglepetést.

\section{Az alcsoportok analizise}

A végpontoknál már elemzett, klinikailag is fontosnak vélt mutatókat az orvosok tapasztalata (nem szakorvos: rezidens, szakorvosjelölt/szakorvos) és a beavatkozás sürgőssége (tervezett/sürgős) szerint is vizsgáltuk ( $6 / D$ táblázat). A két hónap között itt sem volt klinikailag értékelhető szignifikáns eltérés. Érdekesség, hogy a 2. hónapban a sikeres első intubációk kapcsán a nem szakorvosok lényegesen rosszabbul teljesítettek (RR: 3,59, 95\% CI: $1,4-8,65 \%, p=0,0044)$, mint az ellenórző lista előtti hónapban. A posztindukciós hipotenzió analízisekor áprilisban a nem szakorvosok tevékenysége, májusban a sürgősségi beavatkozások jelentettek magasabb, szignifikáns különbségű rizikót.

\section{Megbeszélés}

A vizsgálat fő célja az volt, hogy felmérje: egy ellenőrző lista milyen hatással lehet a nehéz légúti helyzetek menedzseléséhez társuló rövid távú szövődmények alakulására. Tanulmányunk összességében nem támasztotta alá azt a feltételezésünket, hogy egy ellenőrző lista klinikailag is értékelhető mértékben csökkenti a váratlan nehéz 
6/D táblázat | Klinikailag relevánsnak vélt mutatók, alcsoportok analízise az orvosok végzettsége, a beavatkozások sürgőssége szerint

\begin{tabular}{|c|c|c|c|}
\hline $\begin{array}{l}\text { Légútbiztosítási manôverek; } \\
\text { szövődmények }\end{array}$ & $\begin{array}{l}\text { A szövődmények gyakorisága az összes } \\
\text { értékelhető adatlap arányában; } \\
\text { ellenőrző lista előtt } \\
\text { április: } n=439 \text { (\%) }\end{array}$ & $\begin{array}{c}\text { A szövődmények gyakorisága az összes } \\
\text { értékelhető adatlap arányában; } \\
\text { ellenőrző lista birtokában } \\
\text { május: } n=423 \text { (\%) }\end{array}$ & $\begin{array}{c}\text { Statisztika: } \\
\mathrm{p}\end{array}$ \\
\hline $\begin{array}{l}\text { Váratlan nehéz légút } \\
\text { Sürgős/tervezett esetek } \\
\text { RR }(95 \% \mathrm{CI}), \mathrm{p} \\
\mathrm{Nem} \mathrm{SZO}(\mathrm{Re}+\mathrm{SZJ}) / \mathrm{SZO} \\
\mathrm{RR}(95 \% \mathrm{CI}), \mathrm{p}\end{array}$ & $\begin{array}{c}11 / 21 \\
0,83(0,41-1,67), 0,6011 \\
11(3+8) / 21 \\
0,61(0,30-1,23), 0,1679\end{array}$ & $\begin{array}{c}8 / 18 \\
0,76(0,34-1,71), 0,5076 \\
13(4+9) / 13 \\
0,87(0,41-1,83), 0,7178\end{array}$ & $\begin{array}{l}0,7872 \\
0,288\end{array}$ \\
\hline $\begin{array}{l}\text { Váratlanul nehéz ETI } \\
\text { Sürgős/tervezett esetek } \\
\text { RR (95\% CI }), p \\
\text { Nem SZO }(\text { Re + SZJ) / SZO } \\
\text { RR }(95 \% \text { CI }), p\end{array}$ & $\begin{array}{c}7 / 11 \\
0,78(0,31-1,94), 0,5919 \\
6(3+3) / 12 \\
0,64(0,25-1,66), 0,3623\end{array}$ & $\begin{array}{c}7 / 9 \\
1,07(0,41-2,78), 0,8806 \\
7(2+5) / 9 \\
0,88(0,34-2,28), 0,7951\end{array}$ & $\begin{array}{c}1 \\
0,7254\end{array}$ \\
\hline $\begin{array}{l}\text { Posztindukciós deszaturáció } \\
\text { Sürgös/tervezett esetek } \\
R R, p \\
\text { Nem } S Z O(R e+S Z J) / S Z O \\
R R, p\end{array}$ & $\begin{array}{c}6 / 3 \\
3,12,0,1633 \\
5(4+1) / 4 \\
1,45,0,7386\end{array}$ & $\begin{array}{c}5 / 3 \\
2,86,0,15 \\
3(0+3) / 5 \\
0,52,0,4811\end{array}$ & $\begin{array}{c}1 \\
0,6372\end{array}$ \\
\hline $\begin{array}{l}\text { Posztindukciós hipotenzió } \\
\text { Sürgös/tervezett esetek } \\
R R(95 \% C I), p \\
\text { Nem } S Z O(R e+S Z J) / S Z O \\
R R(95 \% C I), p\end{array}$ & $\begin{array}{c}17 / 18 \\
1,41(0,75-2,67), 0,2812 \\
24(2+22) / 11 \\
2,44(1,23-4,86), 0,0108\end{array}$ & $\begin{array}{c}20 / 18 \\
1,89(1,03-3,47), 0,0372 \\
20(3+17) / 18 \\
0,97(0,53-1,78), 0,9239\end{array}$ & $\begin{array}{l}0,9106 \\
0,2497\end{array}$ \\
\hline
\end{tabular}

$\mathrm{CI}$ = konfidenciaintervallum; $\mathrm{n}$ = feldolgozott, értékelt adatlapok száma; $\mathrm{Re}=$ rezidens; $\mathrm{RR}$ = relatív rizikó; SZJ = szakorvosjelölt; SZO = szakorvos

légúti esetek számát, illetve a rövid távú szövődmények előfordulását.

A légútbiztosításban ellenőrző listák bevezetését eddig elsősorban sürgősségi helyzetekben végzett intubációkra javasolták. Smith és mtsai [19] egy standardizált ellenőrző lista bevezetésétől várták a szövődmények (deszaturáció, hányás, nyelőcsőbe intubálás, súlyos hipotenzió, keringésleállás) arányának csökkenését. Az ellenőrző lista előtti 9,2\%-os szövődményarány 1,5\%-ra csökkent. Long és mtsai [20] komplex csomag részeként alkalmaztak ellenőrző listát, és elsődleges végpontként a hipotenzió, hypoxia nélküli sikeres első intubációk arányát (49\% és 78\%) vizsgálták. Janz és mtsai [21] ugyanakkor egy randomizált, multicentrikus vizsgálatban alkalmaztak verbalizált ellenőrző listát, de egyetlen végpontban (deszaturáció, intubációs kísérletek száma, intubációs idő, Cormack-pontszám, keringésleállás, súlyos hipotenzió stb.) sem találtak szignifikáns javulást.

Zeng és mtsai [22] a vizsgált mintán 2,3\%-ban találtak nehéz légutat. Az ETI 4,7\%-a nehéznek, 0,1\%-a sikertelennek bizonyult. Supraglotticus eszközök használatakor 0,4\%-ban találtak nehézséget, sikertelenség az esetek 0,2\%-ában volt. Az arcmaszkos lélegeztetés 1\%-ban okozott nehézséget, sikertelen eset nem volt. Nørskov és mtsai [23] a dán anesztézia-adatbázis vizsgálatakor közel hasonló számokat találtak. Az intubációk 1,86\%-a nehéz volt, 93\%-ban ráadásul váratlanul. A kritériumok finomítása alapján végül a nehéz intubációk 75-93\%-ban megjósolhatatlannak bizonyultak. A nehéznek várt eseteknek csak a 25\%-a lett valóban nehéz intubáció. Maszkos léle- geztetésnél nehézséget 0,66\%-ban mértek, ezek 94\%-a váratlan volt. Langeron és mtsai szerint [24] a nehéz arcmaszkos lélegeztetés a vizsgálatukban $5 \%$-os előfordulást mutatott, ezek 87\%-a lett váratlan esemény. Más vizsgálatok a nehéz intubációk váratlan előfordulását alacsonyabbnak, 50\%-nak és 52\%-nak [25, 26] találták. Látható, hogy pontos számok nem állnak rendelkezésre a váratlan nehéz légúti esetek előfordulásának egyértelmü meghatározására, de a következő adatok támpontot adhatnak: nehéz AML: 0,9-1,4-2,2\% [27-29], nehéz ETI: 1,9-5,3-5,8\% [30-32], nehéz LML: 0,42-2-4,7\% [33$35]$.

Eredményeink számos tekintetben összevethetők az irodalmi áttekintés adataival, hiszen vizsgálatunkban hasonlóan magas számot $(62-76,47 \%)$ mutatott a váratlan események aránya, és a várt nehéz légúti esetek kb. 1/4-e $(20,5 \%-25,5 \%)$ bizonyult valóban nehéznek. A váratlan nehéz légúti helyzetek arányát magasabbnak, 6-10\% közöttinek vártuk saját anyagunkban (7,29\% és 6,14\%). Ez igazolódott, ugyanakkor a feltételezett jelentős javulás nem történt meg az ellenőrző lista birtokában. A minor szövődmények előfordulása, a laringeális maszk használatának nehézségei szintén korrelálnak a nemzetközi adatokkal, a nehéz intubációk és a sikeres első intubáció aránya viszont kissé elmarad azoktól. Ennek hátterében a döntően speciális (baleseti sérültek) beteganyag, valamint nagyobb számú fiatal kolléga felügyelt, de a kompetenciájuk határát nem túllépő, önálló tevékenysége lehet. 
A legvalószínúbb oka annak, hogy az előzetesen várt feltételezéseket a megfigyelt eredmények nem igazolták vissza, az, hogy a szakemberek már birtokában lehettek a tudásnak. A speciális, elsősorban baleseti sérültek légútbiztosításának menedzselése mindig is elvárás volt az intézetben. Rendelkezésre állnak a nehéz légút megoldását segítő algoritmusok, protokollok, speciális eszközök, rendszeres elméleti és gyakorlati képzést kapnak az újonnan belépő aneszteziológusok. Más tudományos vizsgálat résztvevőjeként a dolgozók zöme haladó képzéshez (workshop) jutott, továbbá a MAITT légútbiztosítási szekciójának vezetője is tagja az osztálynak. Világosak a kompetenciahatárok, várható és váratlan nehézség esetén pedig azonnali segítség mindig rendelkezésre áll.

$\mathrm{Az}$ adatlapok kitöltési aránya igen magas volt, ezért reprezentatívnak tekinthetők az eredmények. A vizsgálat korlátait jelentheti viszont, hogy egy centrumban zajlott, és bár prospektív módon történt az adatgyüjtés, intervenció előtti-utáni periódust vizsgált. Randomizálás nem történt, a beavatkozást végző orvosok heterogén csoportot alkottak egy adott hónapon belül. A részletes ellenőrző listának az előnye mellett hátránya is volt: sürgősségi és nem sürgôsségi beteganyagon globálisan került alkalmazásra. A lista egyes elemei nem kerültek külön elemzésre. Bár az ellenőrző listák minden munkafolyamatnál ott voltak, és oktatásuk teljes részletességgel megtörtént, kitöltésük beavatkozásonként nem volt elvárás. Hátrány volt továbbá, hogy a másnapi utánkövetéskor értékes adatok is elvesztek, például egyes betegek korai távozásakor. Más vizsgálatokhoz hasonlóan az eredményeket kissé torzíthatja, hogy várható nehéz légút esetén, a problémákat elkerülendő, eleve supraglotticus eszköz (LM) került alkalmazásra, így a nehéz intubációs esetek száma alacsonyabb lehet a valósnál. Ez a szemlélet ugyanakkor nem tér el a hazai és a nemzetközi gyakorlattól.

\section{Következtetés}

A légútbiztosítás során a betegbiztonság fokozására számos lehetőség áll rendelkezésre. Idetartozik az oktatás, a skill-labor, illetve az egyes lépések elvégzését támogató ellenőrző lista bevezetése. A jelen vizsgálat ugyanakkor nem támasztotta alá hipotézisünket, miszerint az ellenőrző lista önmagában csökkentené a légútbiztosítás rövid távú szövődményeit egy olyan intézetben, ahol ezen beavatkozásokra rutinszerüen sor kerül. További vizsgálatok szükségesek annak érdekében, hogy az egyes tevékenységek során az ellenőrző lista mely elemei, milyen módon és mértékben lehetnek képesek a rendszerhibák kiszưrésén keresztül hatni a javítandó morbiditási és mortalitási adatokra.

Anyagi támogatás: A szerzők a közlemény elkészülésének alapjául szolgáló kutatómunkához és a cikk megírásához anyagi juttatásban nem részesültek.
Szerzői munkamegosztás: Sz. Z. P.: A szakirodalom áttekintése, a kézirat koncepciójának megalkotása, szövegezése, az adatok feldolgozása. F. J., S. P.: Az adatok gyưjtése, a kézirat áttekintése, a szöveg javítása. B. Zs., D. E.: A kézirat kritikus áttekintése, véleményezése. A cikk végleges változatát valamennyi szerző elolvasta és jóváhagyta.

Érdekeltségek: A szerzőknek nincsenek érdekeltségeik.

\section{Köszönetnyilvánítás}

A szerzők szeretnének köszönetet mondani az osztály dolgozóinak lelkes támogatásukért.

Külön köszönet illeti Vásárhelyi Barna professzor urat és Tassonyi Edömér professzor urat kritikus észrevételeikért, tanácsaikért.

\section{Irodalom}

[1] Apfelbaum JL, Hagberg CA, Caplan RA, et al. Practice guidelines for management of the difficult airway: an updated report by the American Society of Anesthesiologists Task Force on Management of the Difficult Airway. Anesthesiology 2013; 118 : 251-270.

[2] Frerk C, Mitchell VS, McNarry AF, et al. Difficult Airway Society 2015 guidelines for management of unanticipated difficult intubation in adults. Br J Anaesth. 2015; 115: 827-848.

[3] Patel A, Nouraei S. Transnasal Humidified Rapid-Insufflation Ventilatory Exchange (THRIVE): a physiological method of increasing apnoea time in patients with difficult airways. Anaesthesia 2015; 70: 323-329.

[4] Chrimes N. The vortex: a universal 'high-acuity implementation tool' for emergency airway management. Br J Anaesthesia 2016; 117(Suppl 1): i20-i27.

[5] Mark LJ, Herzer KR, Cover R, et al. Difficult airway response team: a novel quality improvement program for managing hospital-wide airway emergencies. Anesth Analg. 2015; 121: 127139.

[6] Cook TM, Woodall N, Frerk C. Major complications of airway management in the UK: results of the Fourth National Audit Project of the Royal College of Anaesthetists and the Difficult Airway Society. Part 1. Anaesthesia. Br J Anaesth. 2011; 106: 617-631.

[7] Cook TM, Woodall N, Harper J, et al. Major complications of airway management in the UK: results of the Fourth National Audit Project of the Royal College of Anaesthetists and the Difficult Airway Society. Part 2: Intensive care and emergency departments. Br J Anaesth. 2011; 106: 632-642.

[8] Peterson GN, Domino KB, Caplan RA, et al. Management of the difficult airway: a closed claims analysis. Anesthesiology 2005; 103: 33-39.

[9] Cook TM, Bland L, Mihai R, et al. Litigation related to anaesthesia: an analysis of claims against the NHS in England 19952007. Anaesthesia 2009; 64: 706-718.

[10] Cook TM, Woodall N, Frerk C. A national survey of the impact of NAP4 on airway management practice in United Kingdom hospitals: closing the safety gap in anaesthesia, intensive care and the emergency department. Br J Anaest. 2016; 117: 182-190.

[11] Kheterpal S, Healy D, Aziz MF, et al., Multicenter Perioperative Outcomes Group (MPOG) Perioperative Clinical Research Committee. Incidence, predictors, and outcome of difficult mask ventilation combined with difficult laryngoscopy: a report from the Multicenter Perioperative Outcomes Group. Anesthesiology 2013; 119: 1360-1369. 
[12] Koh W, Kim H, Kim K, et al. Encountering unexpected difficult airway: relationship with the intubation difficulty scale. Korean J Anesthesiol. 2016; 69: 244-249.

[13] Higgs A, McGrath BA, Goddard C, et al. Guidelines for the management of tracheal intubation in the critically ill adult. $\mathrm{Br} \mathrm{J}$ Anaest. 2018; 120: 323-352.

[14] Huitink JM, Bouwman RA. The myth of the difficult airway: airway management revisited. Anaesthesia 2015; 70: 244-249.

[15] Han R, Tremper KK, Kheterpal S, et al. Grading scale for mask ventilation. Anesthesiology 2004; 101: 267.

[16] Sakles JC, Mosier JM, Patanwala AE, et al. First pass success without hypoxemia is increased with the use of apneic oxygenation during rapid sequence intubation in the emergency department. Acad Emerg Med. 2016; 23: 703-710.

[17] Bodily JB, Webb HR, Weiss SJ, et al. Incidence and duration of continuously measured oxygen desaturation during emergency department intubation. Ann Emerg Med. 2016; 67: 389-395.

[18] Weingart SD, Levitan RM. Preoxygenation and prevention of desaturation during emergency airway management. Ann Emerg Med. 2012; 59: 165-175.el.

[19] Smith KA, High K, Collins SP, et al. A preprocedural checklist improves the safety of emergency department intubation of trauma patients. Acad Emerg Med. 2015; 22: 989-992.

[20] Long E, Cincotta DR, Gridlay J, et al. A quality improvement initiative to increase the safety of pediatric emergency airway management. Pediatr Anaesth. 2017; 27: 1271-1277.

[21] Janz DR, Semler MW, Joffe AM, et al., Check-UP Investigators, Pragmatic Critical Care Research Group. A multicenter randomized trial of a checklist for endotracheal intubation of critically ill adults. Chest 2018; 153: 816-824.

[22] Zeng Z, Tay WC, Saito T, et al. Difficult airway management during anesthesia: a review of the incidence and solutions. J Anaesthesiol Crit Care 2018; 1: 5.

[23] Nørskov AK, Rosenstock CV, Wetterslev J, et al. Diagnostic accuracy of anaesthesiologists' prediction of difficult airway management in daily clinical practice: a cohort study of 188064 patients registered in the Danish Anaesthesia Database. Anaesthesia 2015; 70: 272-281.
[24] Langeron O, Masso E, Huraux C, et al. Prediction of difficult mask ventilation. Anesthesiology 2000; 92: 1229-1236.

[25] Wilson ME. Predicting difficult intubation. Br J Anaesth. 1993; 71: 333-334.

[26] Paix AD, Williamson JA, Runciman WB. Crisis management during anaesthesia: difficult intubation. BMJ Qual Saf. 2005; 14: e5.

[27] Rose DK, Cohen MM. The airway: problems and predictions in 18,500 patients. Can J Anaesth. 1994; 41: 372-383.

[28] Kheterpal S, Han R, Tremper KK, et al. Incidence and predictors of difficult and impossible mask ventilation. Anesthesiology 2006; 105: 885-891.

[29] Kheterpal S, Marin L, Shanks AM, et al. Prediction and outcomes of impossible mask ventilation: a review of 50,000 anaesthetics. Anesthesiology 2009; 110: 891-897.

[30] Rose DK, Cohen MM. The incidence of airway problems depends on the definition used. Can J Anaesth. 1996; 43: 30-34.

[31] Lundstrøm LH, Møller AM, Rosenstock C, et al. High body mass index is a weak predictor for difficult and failed tracheal intubation: a cohort study of 91,332 consecutive patients scheduled for direct laryngoscopy registered in the Danish Anesthesia Database. Anesthesiology 2009; 110: 266-274.

[32] Shiga T, Wajima Z, Inoue T, et al. Predicting difficult intubation in apparently normal patients: a meta-analysis of bedside screening test performance. Anesthesiology 2005; 103: 429-437.

[33] Saito T, Chew ST, Liu WL, et al. A proposal for a new scoring system to predict difficult ventilation through a supraglottic airway. Br J Anaesth. 2016; 117(Suppl 1): i83-i86.

[34] Cook TM, Lee G, Nolan JP. The ProSeal laryngeal mask airway: a review of the literature. Can J Anesth. 2005; 52: 739-760.

[35] Cook TM, Trümpelmann P, Beringer R, et al. A randomised comparison of the Portex Softseal laryngeal mask airway with the LMA-Unique during anaesthesia. Anaesthesia 2005; 60: 12181225 .

(Szücs Zoltán Pál dr.,

Budapest, Fiumei út 17. 7. emelet (AIBO-iroda), 1081 e-mail: zoltanszucsmd@gmail.com)

\section{„Exercitatio artem parat." (Tacitus) (Gyakorlat teszi a mestert.)}

A cikk a Creative Commons Attribution 4.0 International License (https://creativecommons.org/licenses/by/4.0/) feltételei szerint publikált Open Access közlemény, melynek szellemében a cikk bármilyen médiumban szabadon felhasználható, megosztható és újraközölhetö, feltéve, hogy az eredeti szerző és a közlés helye, illetve a CC License linkje és az esetlegesen végrehajtott módosítások feltüntetésre kerülnek. (SID_1) 